\title{
22. CORRELATION OF UPPER CAMPANIAN-LOWER MAESTRICHTIAN CALCAREOUS NANNOFOSSIL ASSEMBLAGES IN DRILL AND PISTON CORES FROM THE FALKLAND PLATEAU, SOUTHWEST ATLANTIC OCEAN ${ }^{1}$
}

\author{
Frank H. Wind, Texaco USA, Los Angeles, California \\ and \\ Sherwood W. Wise, Jr., Department of Geology, Florida State University, Tallahassee, Florida
}

\begin{abstract}
Calcareous nannofossils from upper Campanian-lower Maestrichtian Deep Sea Drilling Project Leg 71 Cores 511-23 and 511-24 are described and correlated with assemblages of similar age from piston and drill cores on the Falkland Plateau, South Atlantic Ocean. The Leg 71 cores partially fill a drilling gap of at least 20 meters left within a thick $(50 \mathrm{~m})$ carbonate section first drilled by DSDP Leg 36 at Site 327. Cores 511-23 and 511-24 both fall within the upper portion of the Biscutum coronum Zone of Wind and demonstrate an overlap in the range of Monomarginatus quaternarius with the ranges of $M$. pectinatus, Misceomarginatus pleniporus, and Biscutum coronum across the Campanian/ Maestrichtian boundary. Resolution of the sequence of highest occurrence datums for the latter species must await the recovery of a more complete section. Comparison of the Site 511 assemblages with those from Islas Orcadas Core 0775-44 to the north confirms earlier speculation that the Falkland Plateau served as an important boundary between major water masses during the Late Cretaceous.
\end{abstract}

\section{INTRODUCTION}

Deep Sea Drilling Project Site $511\left(51^{\circ} 00.28^{\prime} \mathrm{S} ; 46^{\circ}\right.$ $\left.58.30^{\prime} \mathrm{W}\right)$, on the Maurice Ewing Bank of the Falkland Plateau (Fig. 1), was occupied by Glomar Challenger between 15 and 21 January 1980 . Drilling at this site recovered 386 meters of sediment from 632 meters of section penetrated. Of the 70 cores taken at this site, Cores 23 and 24, of Maestrichtian/Campanian age, are treated in this report. The nannoplankton from the remainder of the section, and from other sites, are discussed in Wise (this volume).

DSDP Site 511 is the third locality in the region from which Upper Cretaceous sediments have been recovered. Materials of approximately the same age have been cored previously at DSDP Site 327 and at Islas Orcadas Site 07-75-44. An extensive coring gap in the thick $(50 \mathrm{~m})$ Campanian/Maestrichtian sequence at Site 327, however, has left open several unresolved problems of regional correlation. The purpose of the present paper is to correlate the drill and piston-cored sections at the three sites, and to address unresolved stratigraphic questions.

Site 511 is located approximately 10 kilometers south of Site 327 (DSDP Leg 36). One of the coring objectives for Site 511 was the recovery of additional information on the composition and biostratigraphy of the diverse and provincial Late Cretaceous nannoflora first viewed in the well-preserved samples from the former site. This distinctive Maestrichtian/Campanian nannoflora is described in Wise and Wind (1977), and Wind (1979a, b, in press). Broader aspects of Late Cretaceous biostratigraphy and biogeography are discussed in Ciesielski et al.

\footnotetext{
${ }^{1}$ Ludwig, W. J., Krasheninnikov, V. A., et al., Init. Repts. DSDP, 71: Washington (U.S. Govt. Printing Office).
}

(1977), Ciesielski and Wise (1977), Wind (1979a, b), and Wise et al. (1982).

\section{FLORAL REFERENCES}

Species considered in this study are listed in Appendix A where they are arranged alphabetically by generic epithets. Most bibliographic references for these taxa are presented by Loeblich and Tappan $(1966,1968,1969$, 1970a, 1970b, 1971, 1973) and by Heck (1979a, b, 1980); any not included therein are given in the references. In addition, a number of invalid new combinations made in previous publications (Wise and Wind, 1977; Hattner and Wise, 1980) are validated in Appendix B. These new combinations were invalid as originally published because the journals containing the basionyms were cited indirectly by references to the Loeblich and Tappan indexes rather than directly as required by ICBN Article 33.2 (Stafleu et al., 1978).

\section{DSDP HOLE 327A AND ISLAS ORCADAS CORE 07-74-44}

DSDP Hole 327A, Cores 10 through 13, provided the first glimpse of the distinctive Late Cretaceous calcareous nannoplankton assemblage from the Falkland Plateau region. The assemblage, whose high diversity was unexpected, is composed of more than 75 taxa, of which 20 species and 8 genera were new (see Wise and Wind, 1977). Three salient features which characterize the Falkland Plateau assemblage are (1) the presence of many new species, (2) the extreme nannofloral diversity, and (3) the total or nearly complete absence of many taxa previously considered to be "cosmopolitan" species.

Cores 10 through 12 were dated as Maestrichtian and placed in the Nephrolithus frequens Zone by Wise and Wind (1977). Core 13 was dated as Campanian or Maestrichtian. Subsequent study (Wind, 1979a, b, in press) 


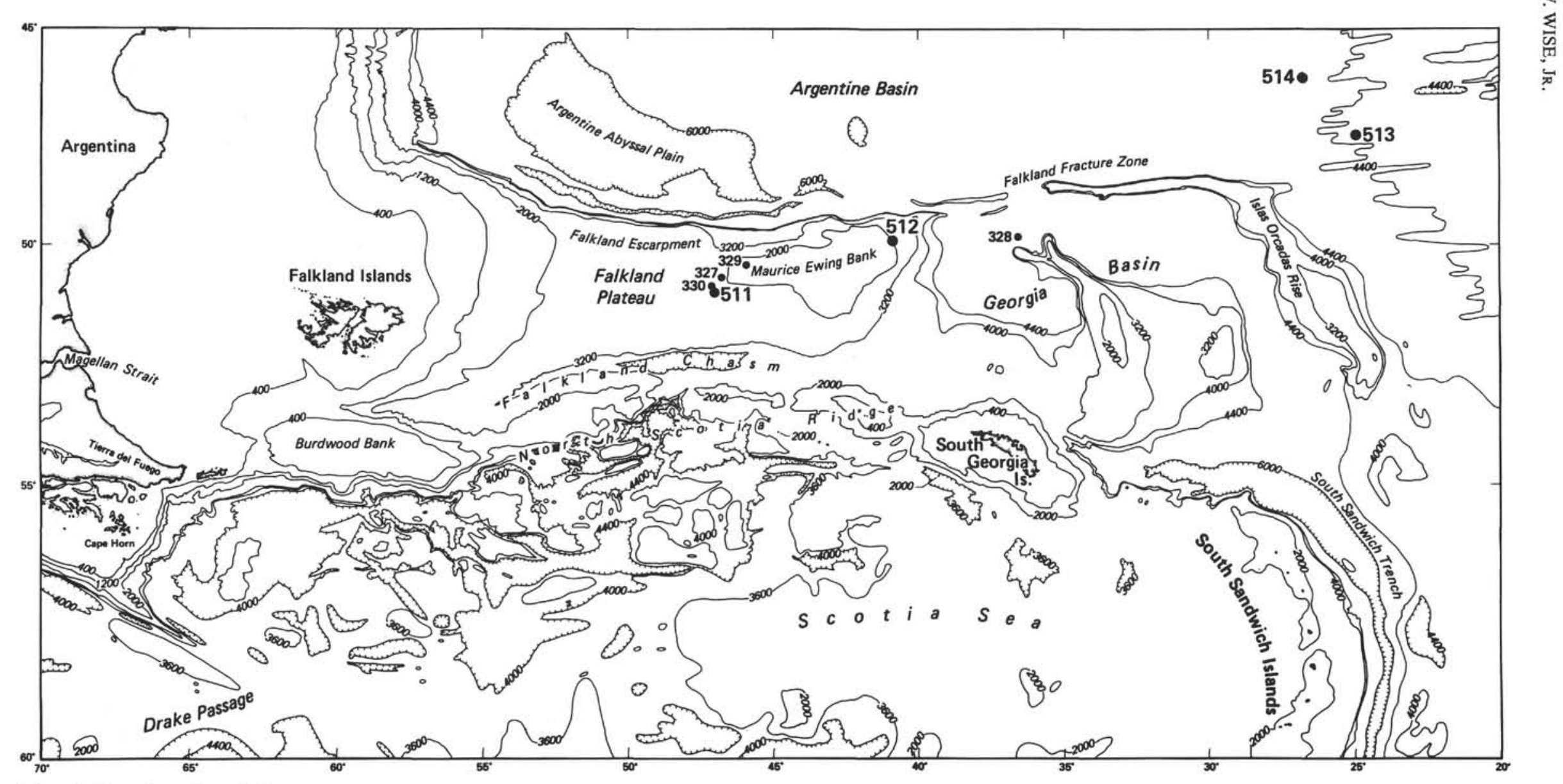

Figure 1. Location of Leg 71 sites. 
has shown the Nephrolithus frequens from Hole 327A to be a totally new species with a totally different biostratigraphic range. Cores 10 through 12 were re-examined and this interval is now dated as early Maestrichtian to possibly earliest middle Maestrichtian. Core 13 is now considered to be latest Campanian (Wind, 1979a, b). Cores 12 and 13 are separated by a composite coring gap and intervals of nonrecovery ranging between 19 and 30 meters (a value of $24 \mathrm{~m}$ was used in the DSDP Leg 36 Initial Reports).

The piston core from Islas Orcadas $07-75-44,160 \mathrm{~km}$ northeast of DSDP Site 327 , consists of $70 \mathrm{~cm}$ of Plio/ Pleistocene glacial-marine sediments and 6 meters of Upper Cretaceous coccolith ooze capped by a thin chert bed. Based on the distribution of planktonic and benthic foraminifers, Sliter (in Ciesielski et al., 1977) dated the upper third of the Cretaceous interval as early Maestrichtian, and the lower two-thirds as late Campanian. Wind $(1979 \mathrm{a}, \mathrm{b})$ correlated the Islas Orcadas core with the short sedimentary section represented by DSDP Core $327 \mathrm{~A}-13$, or with the composite noncored and unrecovered interval just above it.

\section{SITE 511}

Cores 23 and 24 from Site 511 (195.5 to $209 \mathrm{~m}$ subbottom depth) contain calcareous oozes and zeolitic calcareous foraminiferal oozes of Campanian-Maestrichtian age. Core 23 recovered $38 \mathrm{~cm}$ of Cretaceous calcareous ooze overlain by $23 \mathrm{~cm}$ of glauconitic pelagic clay. The clay is barren of nannoplankton, and slides from the calcareous oozes reveal that the nannofloral components are slightly etched but extremely fragmented. Only a small portion of the nannoflora is represented by intact skeletal elements.

Core 24 consists of 9.3 meters of zeolitic calcareous foraminiferal ooze. Preservation of the nannoflora is good, but as with the Core 23 samples, many of the coccolith remains are fragmented (although to a lesser extent). Only after repeated laboratory separation procedures is it possible to obtain clean slides of intact, wellpreserved nannoplankton rivaling those prepared from Site 327 samples. Sixty species were recognized during routine light-microscope examination; two additional species were identified with the scanning electron microscope (see Table 1).

An oddity which occurred during the drilling of Core 24 raised initial questions about the coherence and stratigraphic continuity of the core. Because of poor recovery in several previous cores, it was decided to drill only half the normal interval $(4.5 \mathrm{~m})$ for Core 24 . Surprisingly the entire 9-meter core barrel filled with sediment as the abbreviated interval was drilled. The distribution of species in Table 1, however, indicates that the core represents a coherent, intact section rather than some type of repeated section. The best explanation for this was provided by the drilling superintendent (G. Foss, pers. comm., 1980), who speculated that during the previous coring attempts the ship drifted progressively off station, and some of the drill pipe being added to the string was taken up in the lengthening distance from the ship to the hole. As Core 24 was being drilled, however, the ship was brought back onto station, forcing the extra accumulated drill string into the hole, effectively stabbing a longer section. Because the length of the core greatly exceeded the interval drilled, samples from Sections 4 to 7 of Core 24, are listed by convention as being from the same depth.

\section{BIOSTRATIGRAPHY OF THE FALKLAND PLATEAU SITES}

By comparing the section recovered at DSDP Site 327 with other DSDP localities in the southern Atlantic and Indian Oceans, Wind $(1979 \mathrm{a}, \mathrm{b})$ concluded that Cores 327A-10 through 327A-12 were lower Maestrichtian and that Core 13 was most likely uppermost Campanian. Key biostratigraphic datums used in this correlation are the highest occurrences of Biscutum coronum Wind and Wise, Misceomarginatus pleniporus Wind and Wise, and Monomarginatus pectinatus Wind and Wise, and the lowest occurrence of $M$. quaternarius Wind and Wise. Cores 10 through 12 are placed in the B. magnum Zone, defined as the interval from the highest occurrence of $B$. coronum to the highest occurrence of $B$. magnum. The base of this zone is dated as middle to early Maestrichtian; the top datum is conditionally placed at the boundary between the middle and late Maestrichtian. Core 13 is placed in the Santonian to earliest Maestrichtian $B$. coronum Zone, which, as originally defined, was based on the range of the named species (Wind, 1979a). The bottom of this zone is based upon the reported occurrence of Biscutum sp. cf. B. coronum Wind and Wise in the Santonian of Western Australia (Shafik, 1975).

This high-latitude zonation was proposed to facilitate the correlation of stratigraphic sections in the high southern latitudes, a region in which there is a general lack of many of the generally utilized zonal markers. Many other zonal markers are either totally absent, or are present only sporadically in a cored sequence.

Highest or lowest occurrences of these species have limited biostratigraphic utility. Their local vertical distribution is to some extent likely to be the result of changing positions of currents and water mass boundaries during the Late Cretaceous. In addition, as indicated by Roth (1978), there is the likelihood that the biohorizons of temperature-sensitive coccolith species are most likely time-transgressive. Several workers (Worsley and Martini, 1970; Wind, 1979a) have documented a time-transgressive lowest occurrence boundary for Neprolithus frequens Górka, and Wind (1979a) identified several incongruities in sequences of datums at several Southern Ocean sites which are interpreted to be the result of paleoecological effects.

Wind (1979a, b) placed Islas Orcadas Core 07-75-44 in the $B$. coronum Zone. Based on the assemblage of high-latitude species present and on rare occurrences of previously recognized zonal markers, a later Campanian age was assigned to this core.

In addition to the high-latitude biostratigraphic zonation outlined above, the zonation proposed by Sissingh (1977) was found to be serviceable, in that the species used to define his late Campanian to mid-Maestrichtian 
Table 1. Distribution of upper Campanian-lower Maestrichtian calcareous nannofossils in DSDP Cores 511-23 and 511-24.

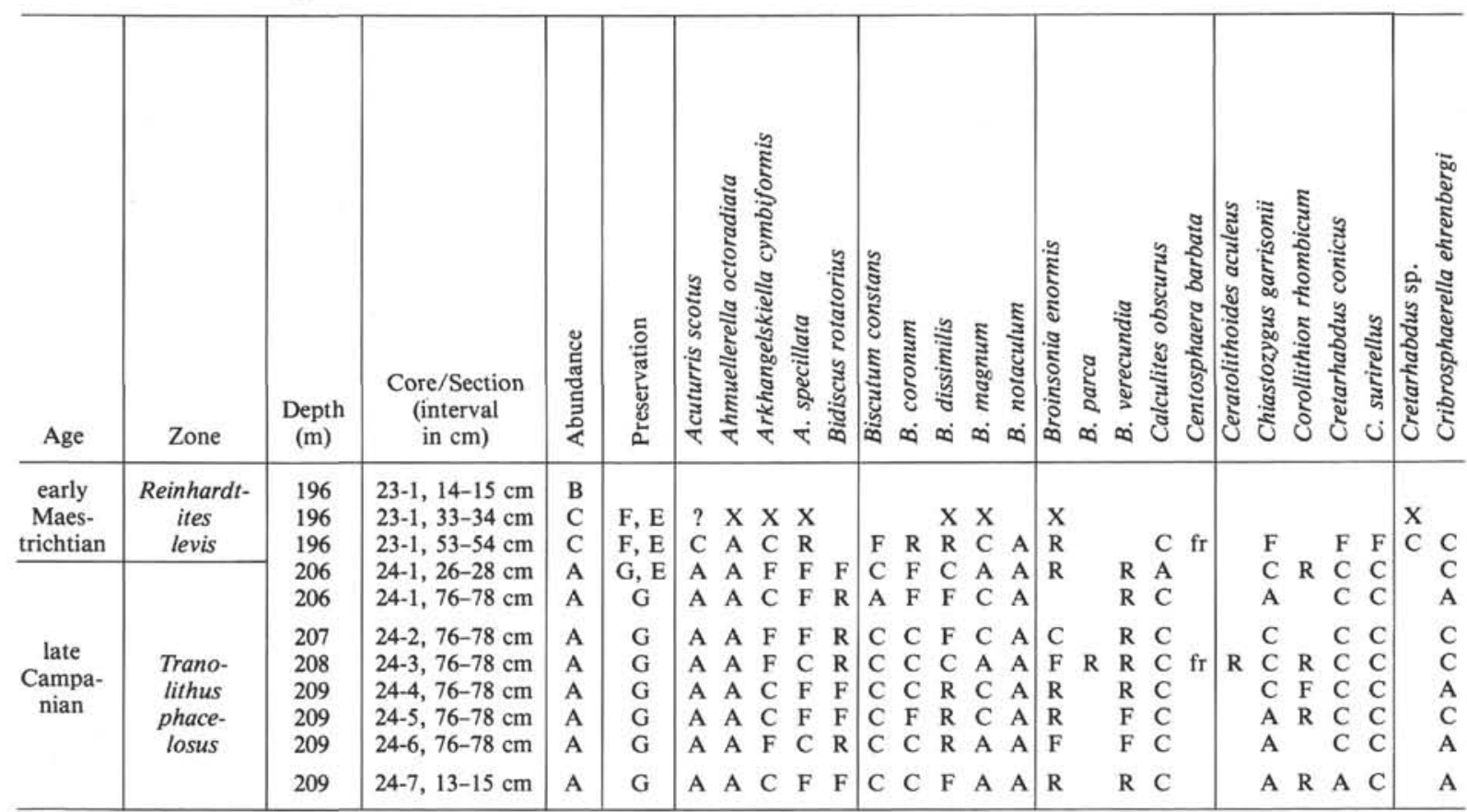

Note: A, abundant; C, common; F, few; R, rare; X, present; B, barren; fr, fragment.

* Detected on SEM.

** Detected on SEM in 511-24-3, 15-17 cm.

zones were present in samples from all three localities considered in this report. The datums recognized are discussed below.

Age determinations of DSDP Sites 327 and 511 and of the Islas Orcadas site sections, as well as their zonal placement in the biostratigraphic sequences of Wind (1979a) and Sissingh (1977), are shown in Figure 2.

Sissingh (1977) defined the Tranolithus phacelosus Partial Range Zone as the interval from the last occurrence of Reinhardtites anthophorus (Deflandre) PerchNielsen emend. to the last occurrence of $T$. phacelosus Stover. This zone is dated as late late Campanian to early early Maestrichtian. We view several of the Tranolithus species to be preservational variations and equate the highest occurrence of all forms of Tranolithus, herein listed under the name Tranolithus orionatus Stover, with the top of this zone.

The $T$. phacelosus Zone is succeeded by the Reinhardtites levis Partial Range Zone, defined as the interval from the last occurrence of $T$. phacelosus $(T$. orionatus) to the last occurrence of Reinhardtites levis Prins and Sissingh. Sissingh (1977) indicates that this zone represents the late part of the early Maestrichtian. These two zones of Sissingh bracket all of the sediments of late Campanian-Maestrichtian age recovered from the three Falkland Plateau sites.

Core 511-23 is dated as latest Campanian. Nannofloras from this core are placed in the $T$. phacelosus Zone of Sissingh (1977) and in the $B$. coronum Zone of Wind (1979a). Core 511-24 is dated as earliest Maestrichtian and placed in the $R$. levis Zone of Sissingh and also in the $B$. coronum Zone. Core 24 is approximately the same age as Islas Orcadas Core 07-75-44. Both the
Islas Orcadas core and DSDP Core 511-24 are slightly younger than DSDP Core $327 \mathrm{~A}-13$, and, along with DSDP Core 511-23, are slightly older than DSDP Cores 327A-10-12.

\section{DISCUSSION}

The examination of the Site 511 cores has in part answered several of the questions concerning the biostratigraphy of key high-latitude species which remained after the initial work on DSDP Leg 36 (Site 327). Monomarginatus pectinatus, Misceomarginatus pleniporus, and Biscutum coronum were restricted to Hole 327A, Core 13, whereas Monomarginatus quaternarius was found only in Cores 327A 10 through 327A-12. Preservation in the Islas Orcadas core was generally too poor to identify any of these species, with the exception of $B$. coronum.

Data from Site 511 show that these species do in fact overlap in range, with the concurrent range of $M$. quaternarius and M. pectinatus, Misceomarginatus pleniporus, and $B$. coronum bracketing the Campanian/ Maestrichtian boundary. The resolution of the sequence of highest occurrence datums for the latter species awaits the recovery of sediments representing the time interval represented by the gap between Cores 511-23 and 511-24.

The presence of Lithraphidites praequadratus Roth (Plate 4, Fig. 3) in Sample 511-24-3, 15-17 cm marks the first time that a representative of this genus has been observed in material from the Falkland Plateau region. Although Roth (1978) indicates a lowest occurrence of this species in the middle lower Maestrichtian, Perch-Nielsen (1979) indicates that this species ranges through the Campanian and Maestrichtian. It is possible that $L$. prae- 
Table 1. (Continued).

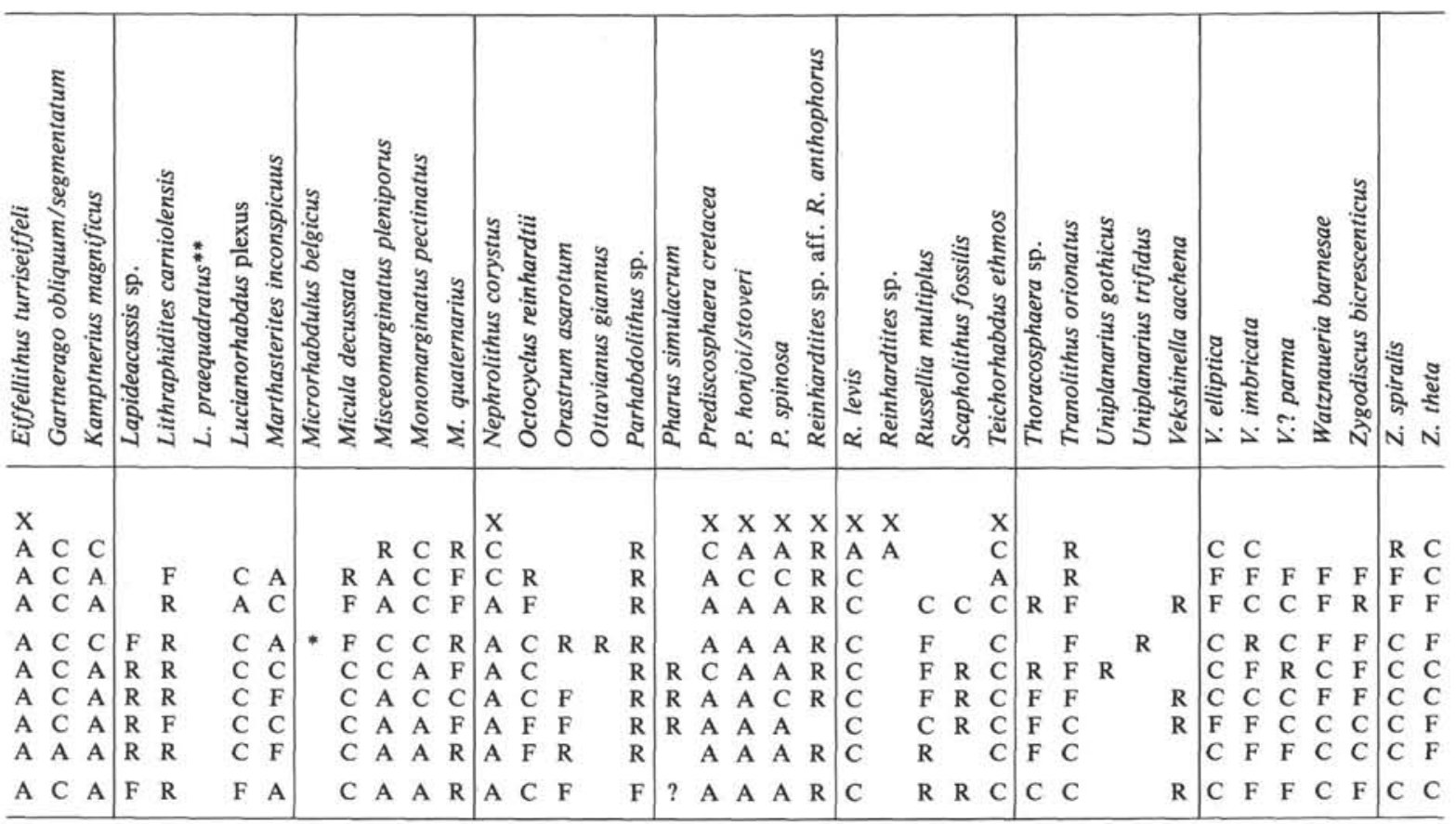

quadratus first appeared early in the Campanian in higher latitudes, but did not range to the mid-paleolatitude site (Blake Plateau) described by Roth until the early Maestrichtian.

Finding material at Site 511 of approximately the same age as in the Islas Orcadas core reinforces the theorized paleoceanographic reconstruction proposed by Ciesielski et al. (1977), who suggested that the Falkland Plateau served as an important boundary between a warmer water mass to the north and a cooler water mass to the south. They found that the lower portion of the Islas Orcadas core contains a warmer water flora quite different from that in DSDP drill sequences to the south. A comparison of DSDP Core 511-24 with the cool water zone in the highest $10 \mathrm{~cm}$ of the Islas Orcadas core shows almost no significant difference in population composition, save those aspects attributed to postdepositional alteration.

The relative abundance of several key species in DSDP Site 511 samples reinforces the biostratigraphic determination and placement of these cores within the interval between DSDP Cores 327A-12 and 327A-13 (see Fig. 3). Nephrolithus corystus Wind demonstrates an increase in relative abundance with time. The lower value for the Core 23 sample is interpreted as being due to problems with preservation. Kamptnerius magnificus also shows a continual increase, as does the Broinsonia-Arkhangelskiella-Gartnerago (“BAG”) group. Eiffellithus becomes less common uphole. The significant differences in abundance for these two sites of Biscutum magnum et al., and Prediscosphaera may reflect local or short-term variation in nannoplankton population composition.

The two features of the DSDP 511 assemblage which link it to the Islas Orcadas material are the presence of Cribrosphaerella ehrenbergi, the absence of $C$. daniae, and the presence of Marthasterites inconspicuus. C. daniae is the only species of Cribrosphaerella in DSDP Cores 327A-10 through 327A-12, while only C. daniae is found in Core 327A-13. It appears that in this region, at about the time of the Campanian/Maestrichtian boundary, the portion of the population represented by $C$. ehrenbergi was replaced by $C$. daniae.

Another feature which populations from the various Falkland Plateau sites have in common is the presence, often in large numbers, of $M$. inconspicuus Deflandre (Plate 4, Fig. 2). This species, which the present authors view as a form of Micula with threefold symmetry, is absent in the higher DSDP 327A cores, but is present in DSDP $327 \mathrm{~A}-13$ and in the Islas Orcadas core, and is abundant in DSDP Core 511-24. The reason for this acme of Marthasterites inconspicuus is not understood, especially in the light of the strong paleoecological control over the distribution of Micula decussata (see Wind, 1979b). Further exploration of this phenomenon would be aided if we could view differences between these two species as extreme examples of ecophenotypic variation.

Several other species may be present in Site 511 samples, but because of the severe fragmentation of the nannoflora they were undetectable. No clearly identifiable specimens of Ceratolithoides aculeus, Lithraphidites carniolensis, L. praequadratus, or Microrhabdulus belgicus were observed in the light microscope. These forms are easily confused with fragments of spines of Eiffellithus, Prediscosphaera, or Reinhardtites, or with corroded panels of Acuturris scotus. Fragments of A. scotus often developed microserrated edges and could be misinterpreted as fragments of specimens of $M$. belgicus.

\section{ACKNOWLEDGMENTS}

We thank Texaco USA (Los Angeles) for use of the scanning electron microscope operated by the first author. Dr. Merton E. Hill critically reviewed the manuscript and Dr. Alfred P. Loeblich provided helpful discussion. Participation by Sherwood W. Wise, Jr. in this 


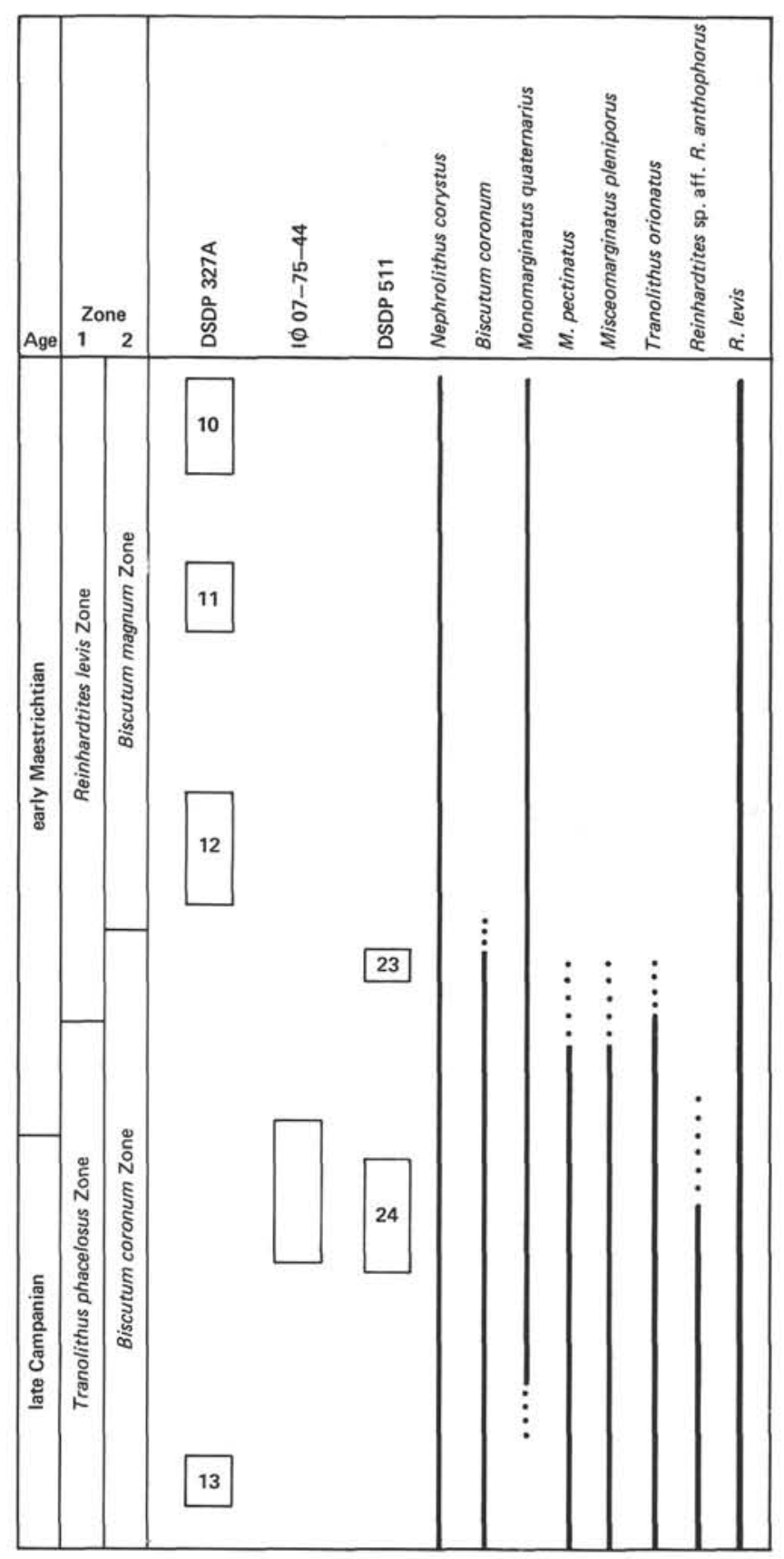

Figure 2. Correlation of DSDP Sites 327 and 511, and Islas Orcadas Core 07-75-44. Zonation 1 is based upon the work of Sissingh (1977); Zonation 2 is from Wind (1979a). The Campanian/Maestrichtian boundary is largely based upon Sliter in Ciesielski et al. (1977). Thickness of each section reflects amount of sediment recovered.

project was supported by NSF grant DPP 8020382 . Sharon Reeves, Mary Parker, and Rob Case helped prepare the manuscript.

\section{REFERENCES}

Black, M., 1965. Coccoliths. Endeavour, 24:131-137. 1967. New names for some coccolith taxa. Proc. Geol. Soc. London, 1640:139-145.

Ciesielski, P. F., Sliter, W. V., Wind, F. H., and Wise, S. W., 1977. Paleoenvironmental analysis and correlation of a Cretaceous Islas Orcadas core from the Falkland Plateau, Southwest Atlantic. Mar. Micropaleontol., 2:27-34.

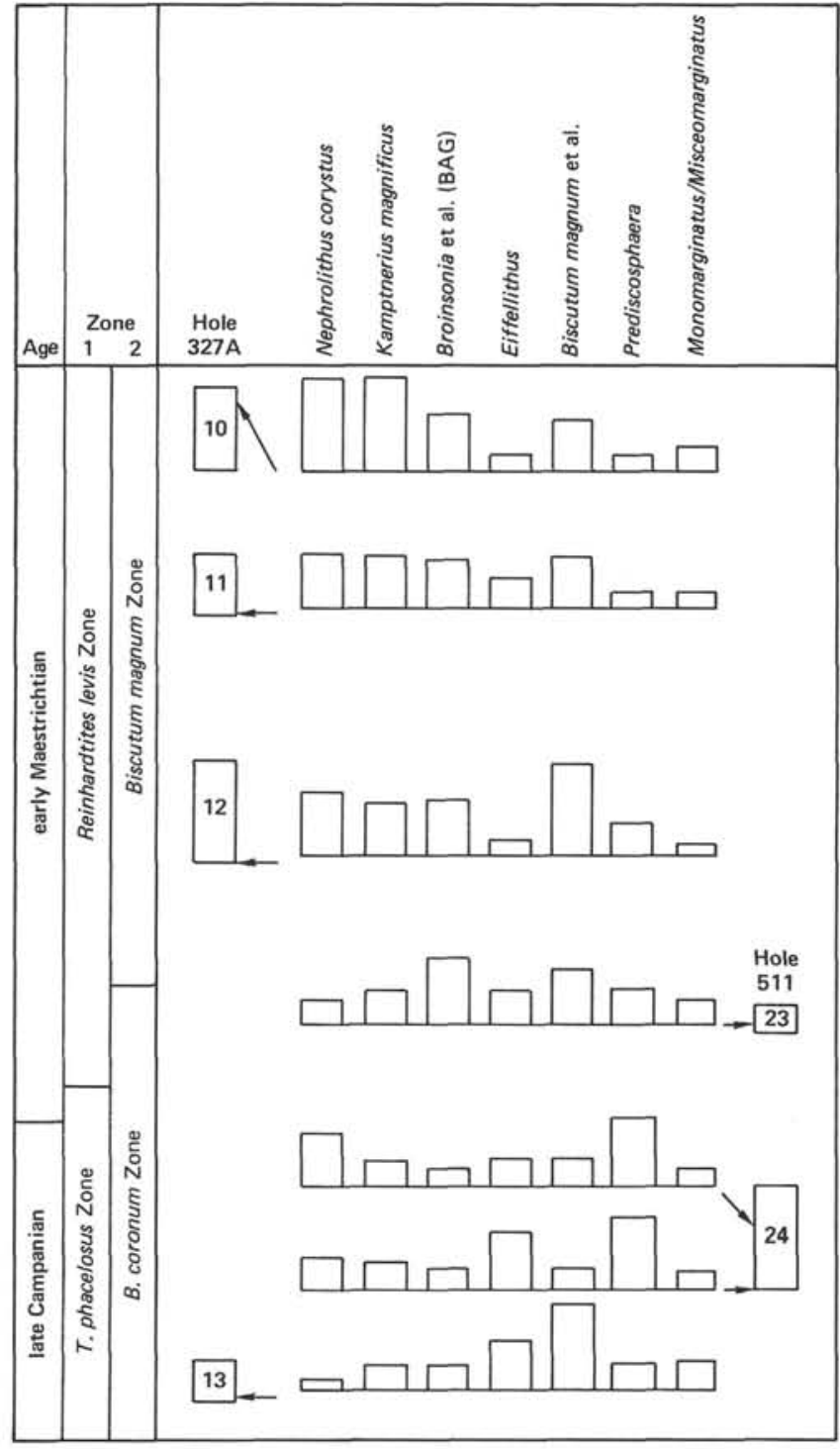

Figure 3. Relative abundance of key species and species groups for samples from DSDP Cores 327A-10-13 and 511-23-24, based upon 300 counts per sample. Broinsonia et al. includes Broinsonia, Arkhangelskiella, and Gartnerago. Biscutum magnum et al. includes B. magnum, B. coronum, and B. dissimilis. Prediscosphae$r a$ includes P. cretacea and $P$. spinosa.

Ciesielski, P. F., and Wise, S. W., 1977. Geologic history of the Maurice Ewing Bank of the Falkland Plateau (Southwest Atlantic sector of the Southern Ocean) based on piston and drill cores. Mar. Geol., 25:175-207.

Deflandre, G., 1959. Sur les nannofossiles calcaires et leur systématique. Rev. Micropaleontol., 2:127-152.

Deflandre, G., and Fert, C., 1954. Observations sur les Coccolithophoridés actuels et fossiles en microscopie ordinaire et électronique. Ann. Paleontol, 40:115-176.

Hattner, J. G., and Wise, S. W., 1980. Upper Cretaceous calcareous nannofossil biostratigraphy of South Carolina. S. C. Geol., 24(2): 41-117.

Heck, S. E. van, 1979a. Int. Nannoplankton Assoc. Newsl., 1(1). 1979b. Int. Nannoplankton Assoc. Newsl., 1(2).

1980. Int. Nannoplankton Assoc. Newsl., 2(1).

Loeblich, A. R., Jr., and Tappan, H., 1966. Annotated index and bibliography of the calcareous nannoplankton. Phycologia, 5: 81-216.

1968. Annotated index and bibliography of the calcareous nannoplankton III. J. Paleontol., 42:584-598. 
1969. Annotated index and bibliography of the calcareous nannoplankton III. J. Paleontol., 43:568-588.

1970a. Annotated index and bibliography of the calcareous nannoplankton IV. J. Paleontol., 44:558-574.

1970b. Annotated index and bibliography of the calcareous nannoplankton VI. Phycologia, 9:157-174.

1971. Annotated index and bibliography of the calcareous nannoplankton VI. Phycologia, 10:315-339. 1973. Annotated index and bibliography of the calcareous nannoplankton VII. J. Paleontol., 47:715-759.

Perch-Nielsen, K., 1979. Calcareous nannofossils from the Cretaceous between the North Sea and the Mediterranean. Aspecte der Kriede Europas: IUGS Series A (Stuttgart), 6:223-272.

Reinhardt, P., 1965. Neue Familien für fossile Kalkflagellaten (Coccolithophoriden, Coccolithineen). Monatsber. Akad. der Wiss. Berlin, 7:30-40.

1969. Neue Coccolithen-Arten aus der Kreide. Monatsber. Akad. Wiss. Berlin, 11:932-938.

Roth, P. H., 1978. Cretaceous nannoplankton biostratigraphy and oceanography of the northwestern Atlantic Ocean. In Benson, W. E., Sheridan, R. E., et al., Init. Repts. DSDP, 44: Washington (U.S. Govt. Printing Office), 731-760.

Shafik, S., 1975. Nannofossil biostratigraphy of the Southwest Pacific, Deep Sea Drilling Project, Leg 30. In Andrews, J. E., Packham, G., et al., Init. Repts. DSDP, 30: Washington (U.S. Govt. Printing Office), 549-598.

Sissingh, W., 1977. Biostratigraphy of Cretaceous calcareous nannoplankton. Geol. Mijnbouw, 56:37-65.

Stafleu, F. A., Demoulin, V., Greuter, W., Hiepko, P., Linczevski, I. A., McVaugh, R., et al. (Eds.), 1978. International Code of Botanical Nomenclature Adopted by the Twelfth International Botanical Congress, Leningrad, July 1975: Utrecht (International Bureau for Plant Taxonomy and Nomenclature).

Stradner, H., and Papp, A., 1961. Tertiäre Discoasteriden aus Osterreich und deren Stratigraphischen Bedeutung mit Hinweisen auf Mexiko, Rumanien und Italien. Jahrb. Geol. Bundesanst. (Wien), Sondeband 7.

Thierstein, H. R., 1974. Calcareous nannoplankton-Leg 26, DSDP. In Davies, T. A., Luyendyk, B. P., et al., Init. Repts. DSDP, 26: Washington (U.S. Govt. Printing Office), 619-668.

Wind, F. H., 1979a. Late Campanian and Maestrichtian calcareous nannoplankton biogeography and high-altitude biostratigraphy [Ph.D. dissert.]. Florida State University, Tallahassee.

, 1979b. Maestrichtian-Campanian Nannofloral Provinces of the Southern Atlantic and Indian Oceans: Washington, D.C. (American Geophysical Union).

, in press. The Genus Nephrolithus Gorka, 1957 (Coccolithophoridae) J. Paleontol.

Wise, S. W., Ciesielski, P. F., MacKenzie, D. T., Wind, F. H., Busen, K. E., Gumbos, A. M., Haq, B. U., Lohmann, G. P., Tjalsma, R. C., Harris, W. K., Hedlund, R. W., Beju, D. N., Jones, D. L., Plafker, G., and Sliter, W. V., 1982. Paleontologic and paleoenvironmental synthesis for the southwest Altantic Ocean basin based on Jurassic to Holocene faunas and floras from the Falkland Plateau. In Craddock, C. (Ed.), Antarctic Geoscience: Madison, Wis. (Univ. of Wisconsin Press), pp. 155-163.

Wise, S. W., and Wind, F. H., 1977. Mesozoic and Cenozoic calcareous nannofossils recovered by DSDP Leg 36 drilling on the Falkland Plateau, Southwest Atlantic sector of the Southern Ocean. In Barker, P. F., Dalziel, I. W. D., et al., Init. Repts. $D S D P, 36$ : Washington (U.S. Govt. Printing Office), 269-492.

Worsley, T., and Martini, E., 1970. Late Maastrichtian nannoplankton provinces. Nature, 225:1242-1243.

\section{APPENDIX A}

\section{Species Considered in This Report}

Acuturris scotus (Risatti) Wind and Wise, 1977

Ahmuellerella octoradiata (Gorka) Reinhardt, 1966

Arkhangelskiella cymbiformis Vekshina, 1959

A. specillata Vekshina, 1959

Bidiscus rotatorius Bukry, 1969

Biscutum constans (Gorka) Black, 1959

B. coronum Wind and Wise, 1977

B. dissimilis Wind and Wise, 1977
B. magnum Wind and Wise, 1977

B. notaculum Wind and Wise, 1977

Broinsonia enormis (Shumenko) Manivit, 1971

B. parca (Stradner) Bukry, 1969

B. verecundia Wind and Wise, 1977

Calculites obscurus (Deflandre) Prins and Sissingh, 1977

Centosphaera barbata Wind and Wise, 1977

Ceratolithoides aculeus (Stradner) Prins and Sissingh, 1977

Chiastozygus garrisonii Bukry, 1969

Corollithion rhombicum (Stradner and Adamiker) Bukry, 1969

Cretarhabdus conicus Bramlette and Martini, 1964

C. surirellus (Deflandre and Fert) Reinhardt, 1970

Cribrosphaerella ehrenbergi (Arkhangelsky) Deflandre

Cribrosphaerella? daniae Perch-Nielsen, 1973

Eiffellithus turriseiffeli (Deflandre and Fert) Reinhardt, 1965

Gartnerago obliquum (Stradner) Reinhardt, 1970

G. segmentatum (Stover) Thierstein, 1974

Kamptnerius magnificus Deflandre, 1959

Lapideacassis sp.

Lithraphidites carniolensis Deflandre, 1963

L. praequadratus Roth, 1978

Lucianorhabdus plexus

Marthasterites inconspicuus Deflandre, 1959

Microrhabdulus belgicus Hay and Towe, 1963

Micula decussata Vekshina, 1959

Misceomarginatus pleniporus Wind and Wise, 1977

Monomarginatus pectinatus Wind and Wise, 1977

M. quaternarius Wind and Wise, 1977

Nephrolithus corystus Wind, 1983

N. frequens Gorka, 1957

Octocyclas reinhardtii (Bukry) Wind and Wise, 1977

Orastrum asarotum Wind and Wise, 1977

Ottavianus giannus Risatti, 1973

Parhabdolithus sp.

Pharus simulacrum Wind and Wise in Wise and Wind, 1977

Prediscosphaera cretacea (Arkhangelsky) Gartner, 1968

P. germania Bukry, 1969

P. honjoi Bukry, 1969

P. spinosa (Bramlette and Martini) Gartner, 1968

$P$. stoveri (Perch-Nielsen) Shafik and Stradner, 1977

Reinhardtites sp. aff. $R$. anthophorus (Deflandre) Perch-Nielsen, 1968

R. levis Prins and Sissingh, 1977

Russellia multiplus (Perch-Nielsen) Wind and Wise, 1977

Scapholithus fossilis Deflandre and Fert, 1954

Teichorhabdus ethmos Wind and Wise, 1977

Thoracosphaera sp.

Tranolithus orionatus Stover, 1966

Uniplanarius gothicus (Deflandre) Hattner and Wise, n. comb.

$U$. trifidus (Stradner) Hattner and Wise, n. comb.

Vekshinella aachena (Bukry) Wind and Wise, 1977

V. elliptica Gartner, 1968

V. imbricata Gartner, 1968

V? parma Wind and Wise, 1977

Watznaueria barnesae (Black) Perch-Nielsen, 1968

Zygodiscus bicrescenticus (Stover) Bukry, 1973

Z. spiralis Bramlette and Martini, 1964

Z. theta (Black) Bukry, 1969

\section{APPENDIX B \\ Validation of New Combinations}

\section{By F. H. Wind and S. W. Wise, Jr.}

The following transfers originally made by Wind and Wise in Wise and Wind (1977) are recombined here in order to validate them in accordance with ICBN Article 33.2 (see discussion under "Floral References" earlier).

Axopodorhabdus albianus (Black) Wind and Wise, n. comb.

Basionym. Podorhabdus albianus Black, 1967, pp. 143-144 (see Black, 1965, fig. 10, for illustration).

Axopodorhabdus dietzmanni (Reinhardt) Wind and Wise, n. comb. Basionym. Ahmuellerella dietzmanni Reinhardt, 1965, p. 30, pl. 1, fig. 1 , text-fig. 1 . 
F. H. WIND, S. W. WISE, JR.

Axopodorhabdus gorkae (Reinhardt) Wind and Wise, n. comb. Basionym. Podorhabdus gorkae Reinhardt, 1969, pl. 1, figs. 1-2.

Tetrapodorhabdus decorus (Deflandre and Fert) Wind and Wise, $\mathrm{n}$. comb.

Basionym. Rhadbolithus decorus Deflandre and Fert, 1954, p. 159, text-fig. 87; pl. 13, figs. 4-6.

2. By M. V. Filewicz, F. H. Wind, and S. W. Wise, Jr.

The following transfer originally made by Filewicz, Wind, and Wise in Wise and Wind (1977) is recombined here in order to validate it in accordance with ICBN Article 33.2 (see discussion under "Floral References" earlier).

Seribiscutum primitivum (Thierstein) Filewicz, Wind, and Wise, n. comb.
Basionym. Cribrosphaerella primitiva Thierstein, 1974, p. 637, pl. 1, figs. 1-3.

3. By J. G. Hattner and S. W. Wise, Jr.

The following transfers originally made by Hattner and Wise (1980) are recombined here in order to validate them in accordance with ICBN Article 33.2 (see discussion under "Floral References" earlier).

Uniplanarius gothicus (Deflandre Hattner and Wise, n. comb.

Básionym. Tetralithus gothicus Deflandre, 1959, p. 138, pl. 3, fig. 25 .

Uniplanarius trifidus (Stradner) Hattner and Wise, n. comb.

Basionym. Tetralithus gothicus trifidus (Stradner) in Stradner and Papp, 1961, p. 124, text-fig. 23/3a-c. 


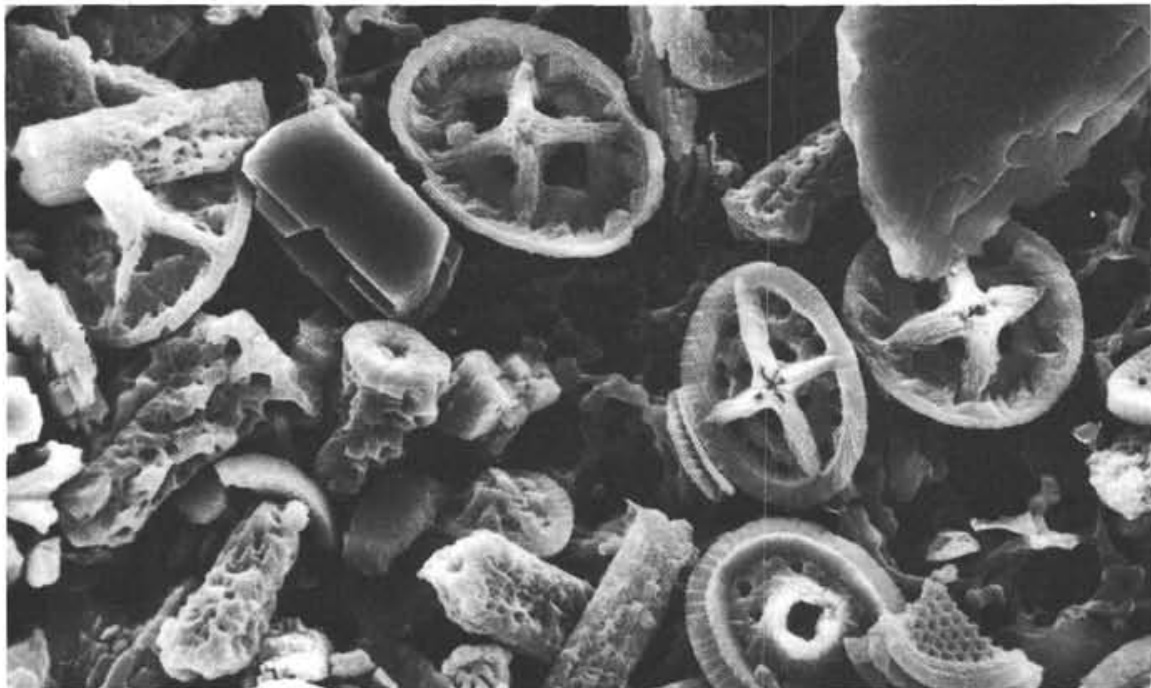

1

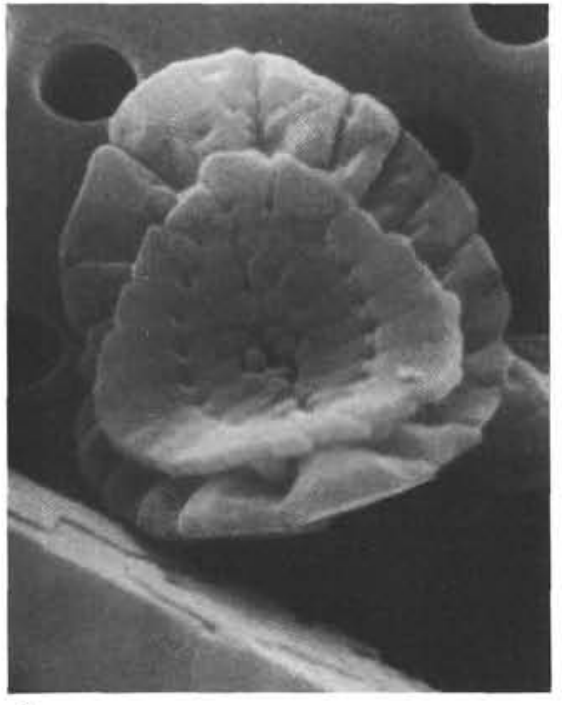

3

$1 \mu \mathrm{m}$

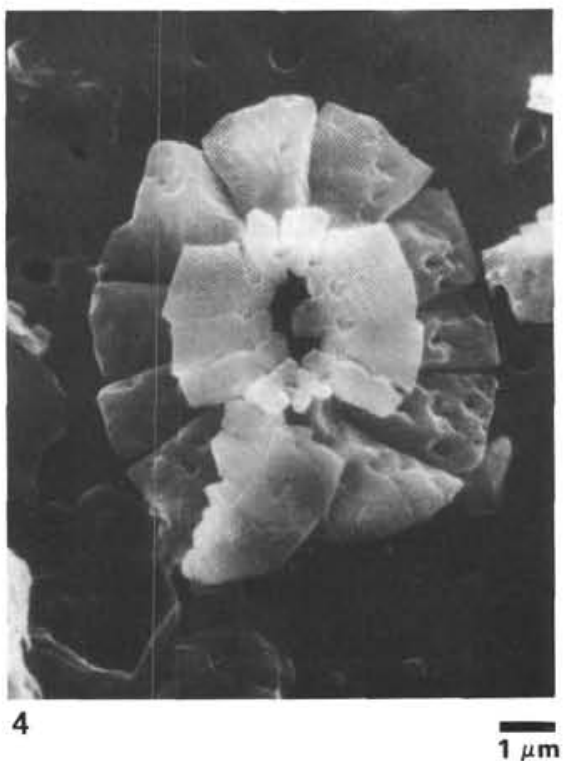

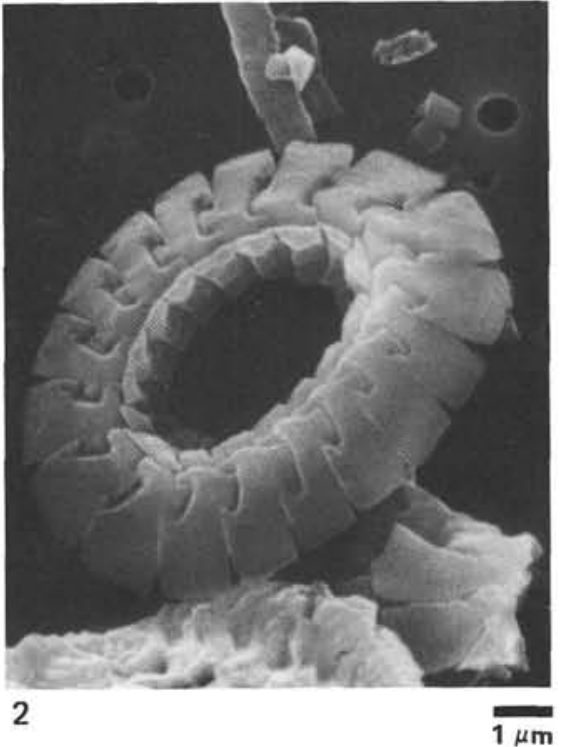

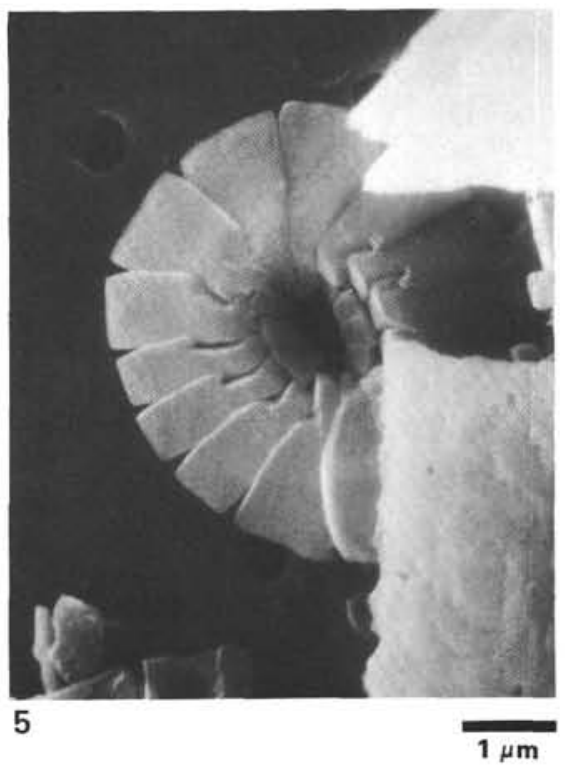

Plate 1. Calcareous nannoplankton from the Falkland Plateau. (All figures are scanning electron micrographs.) 1. Strew mount of settled nannofossil ooze, $\times 1800$, showing abundant coccoliths and a large number of fragments of Acuturris scotus (Risatti) Wind and Wise; Sample 511-24$3,76-78 \mathrm{~cm}$. 2. Biscutum magnum Wind and Wise, distal view, $\times 5800$; Sample $511-24-1,26-28 \mathrm{~cm} . \quad 3$. Biscutum notaculum Wind and Wise, proximal view, $\times 13,500$; Sample $511-24-3,76-78 \mathrm{~cm}$. 4. Biscutum dissimilis Wind and Wise, proximal view, $\times 5800$; Sample 511-24-1, 26-28 $\mathrm{cm}$. 5. Biscutum constans (Górka) Black, distal view, $\times 9000$; Sample 511-24-1, 26-28 cm. 

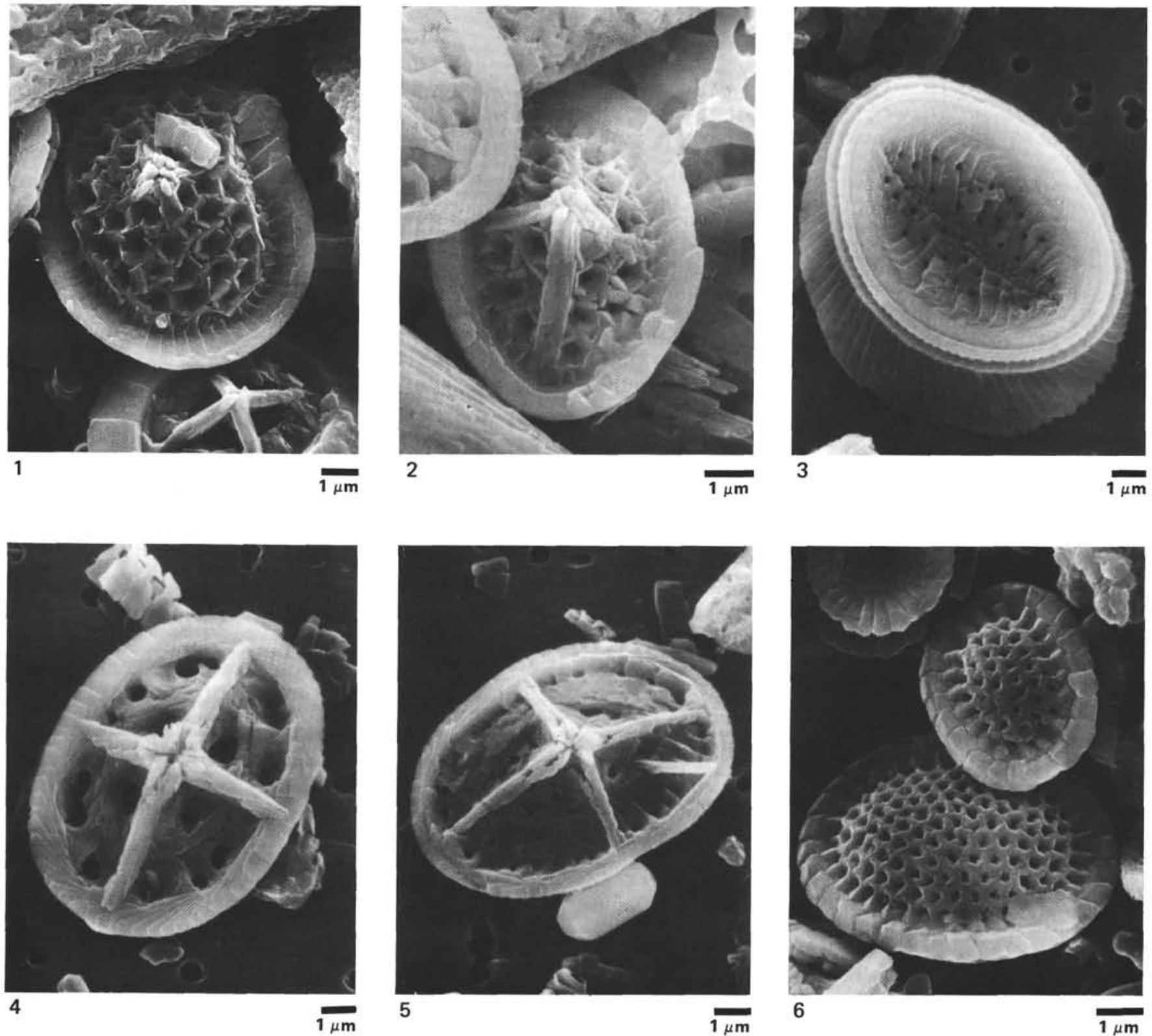

Plate 2. Calcareous nannoplankton from the Falkland Plateau. (All figures are scanning electron micrographs.) 1. Nephrolithus corystus Wind, distal view of reniform morphotype, $\times 5500$; Sample $511-24-3,15-17 \mathrm{~cm} . \quad 2$. Nephrolithus corystus Wind, distal view of elliptical morphotype, $\times 7000$; Sample 511-24-3, 15-17 cm. 3. Kamptnerius magnificus Deflandre, proximal view, $\times 4500$; Sample 511-24-1, 26-28 cm. 4. Monomarginatus pectinatus Wind and Wise, distal view, $\times 5800$; Sample $511-24-1,26-28 \mathrm{~cm} . \quad 5$. Misceomarginatus pleniporus Wind and Wise, distal view, $\times 5800$; Sample 511-24-1, 26-28 cm. 6. Cribrosphaerella ehrenbergi (Arkhangelsky) Deflandre; distal view of two specimens, $\times 7500$; Sample 511-24-3, 76-78 cm. 


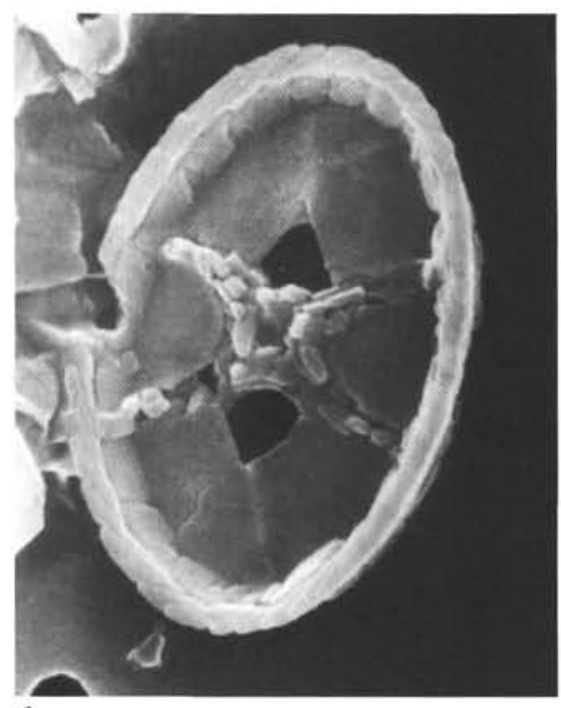

1

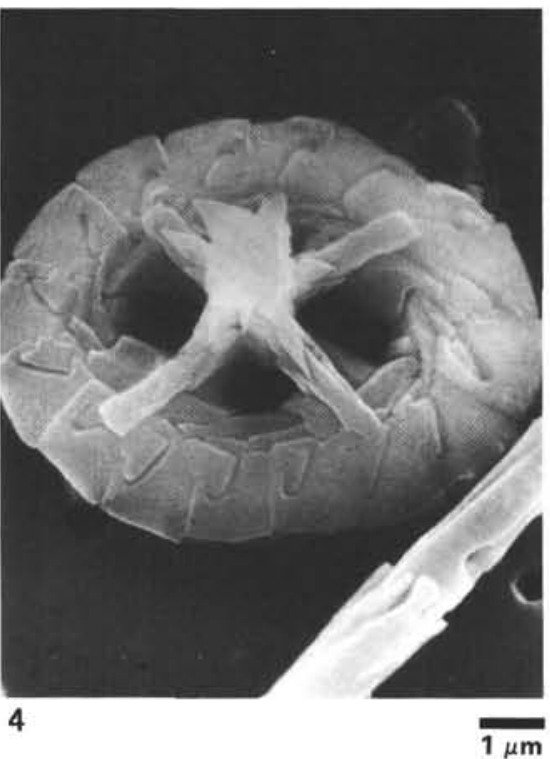

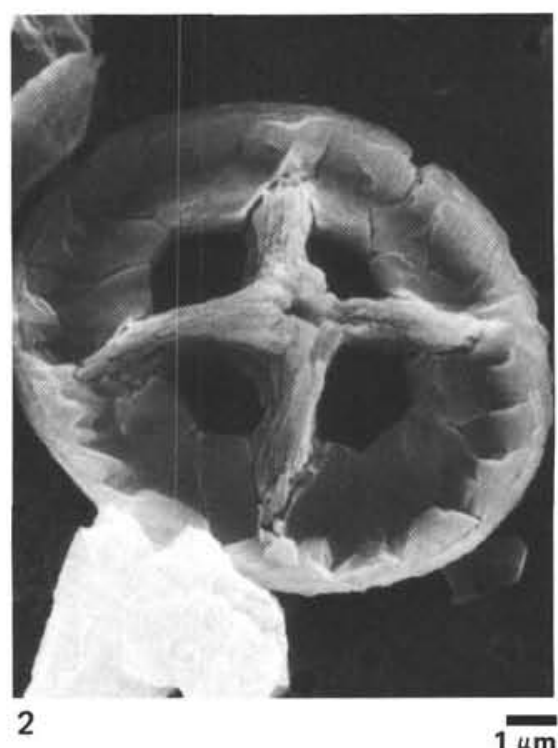
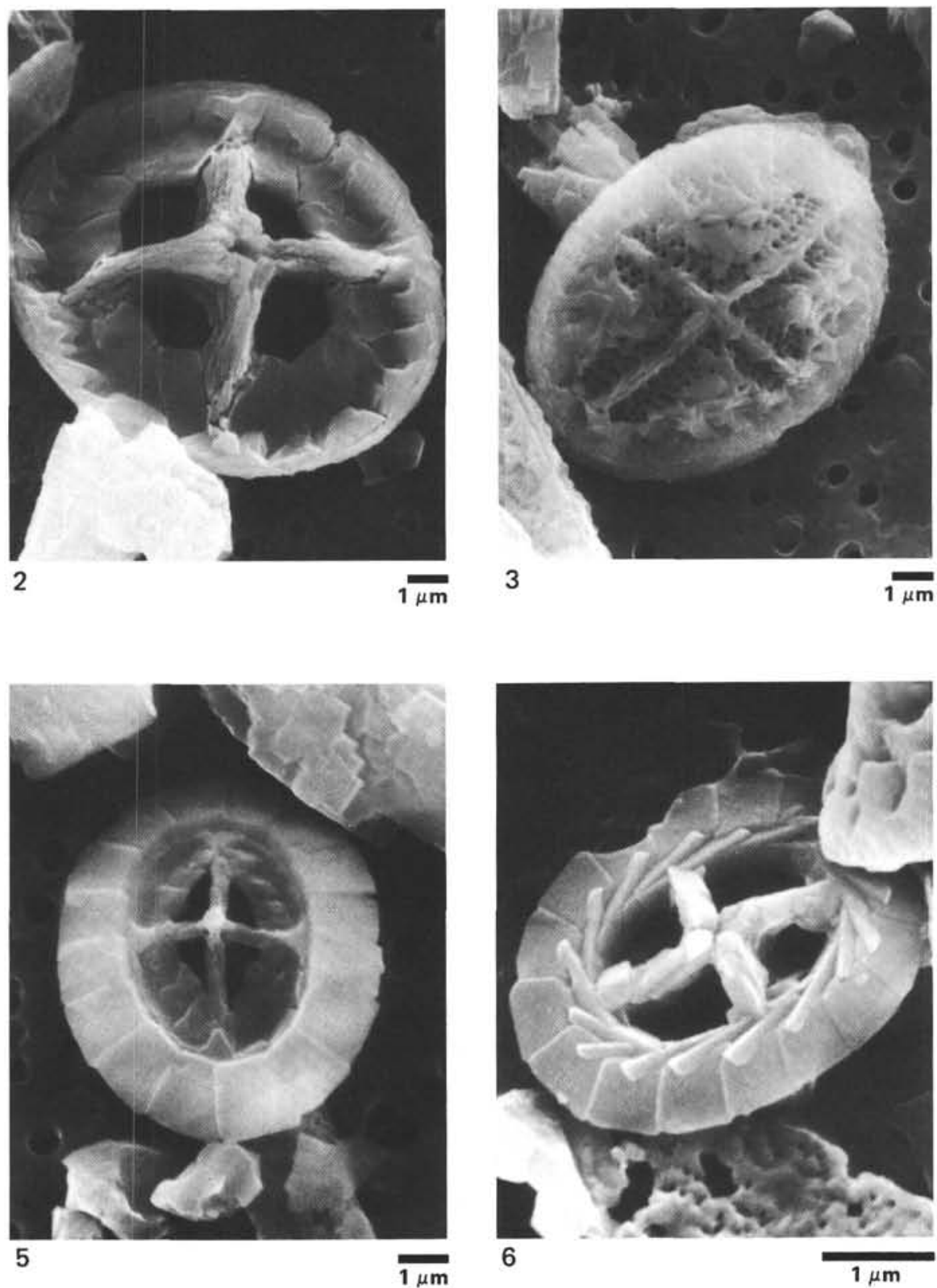

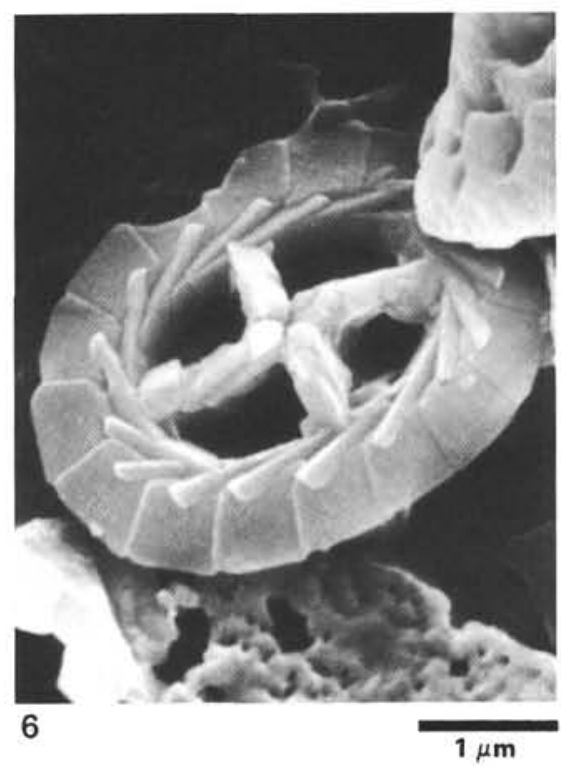

Plate 3. Calcareous nannoplankton from the Falkland Plateau. (All figures are scanning electron micrographs.) 1. Eiffellithus turriseiffeli Deflandre, distal view, $\times 10,000$; Sample $511-24-3,76-78 \mathrm{~cm}$. 2. Eiffellithus turriseiffeli Deflandre, distal view, $\times 4500$; Sample 511-24-1, 26-28

$\mathrm{cm}$. 3. Gartnerago sp. (Stradner) Forchheimer; distal view, $\times 4500$; Sample $511-24-7,13-15 \mathrm{~cm}$. 4. Prediscosphaera cretacea (Arkhangelsky) Gartner, distal view, $\times 6000$; Sample 511-24-1, 26-28 cm. 5. Prediscosphaera spinosa (Bramlette and Martini) Gartner, distal view, $\times 6000$; Sample 511-24-7, 13-15 cm. 6. Prediscosphaera germanica Bukry, distal view, $\times 13,500$; Sample 511-24-3, 76-78 cm. 

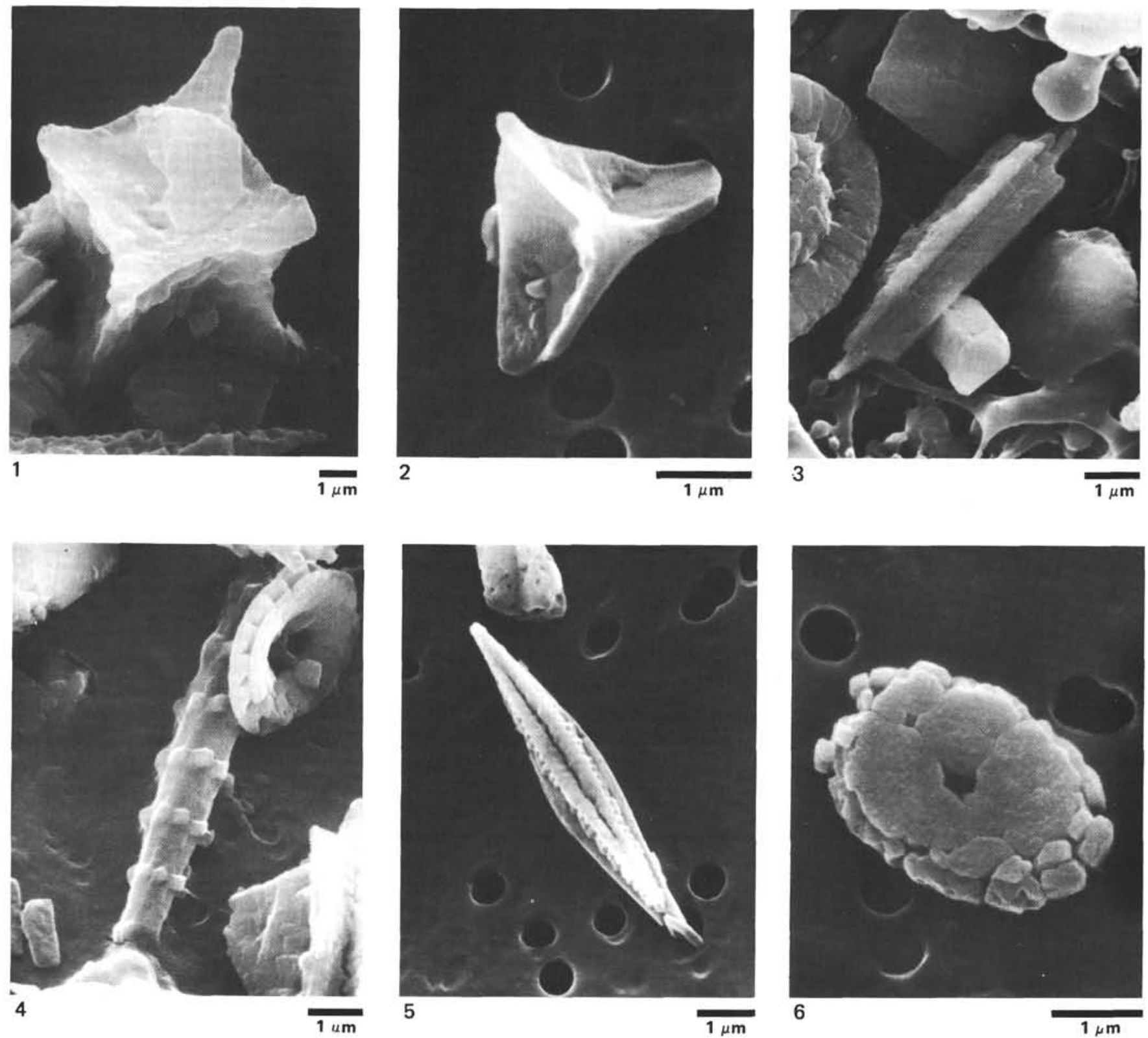

Plate 4. Calcareous nannoplankton from the Falkland Plateau. (All figures are scanning electron micrographs.) 1. Micula decussata Vekshina, $\times 6000$; Sample 511-24-7, 15-17 cm. 2. Marthasterites inconspicuus Deflandre, $\times 15,000$; Sample 511-24-3, 15-17 cm. 3. Lithraphidites praequadratus Roth, $\times 6000$; Sample 511-24-3, 15-17 cm. 4. Microrhabdulus belgicus Hay and Towe, $\times 8400$; Sample 511-24-3, 76-78 cm. 5 . Scapholithus fossilis Deflandre, $\times 9000$; Sample $511-24-3,15-17 \mathrm{~cm} . \quad 6$. Orastrum asarotum Wind and Wise, $\times 13,500$; Sample 511-24-1, 26-28 $\mathrm{cm}$. 


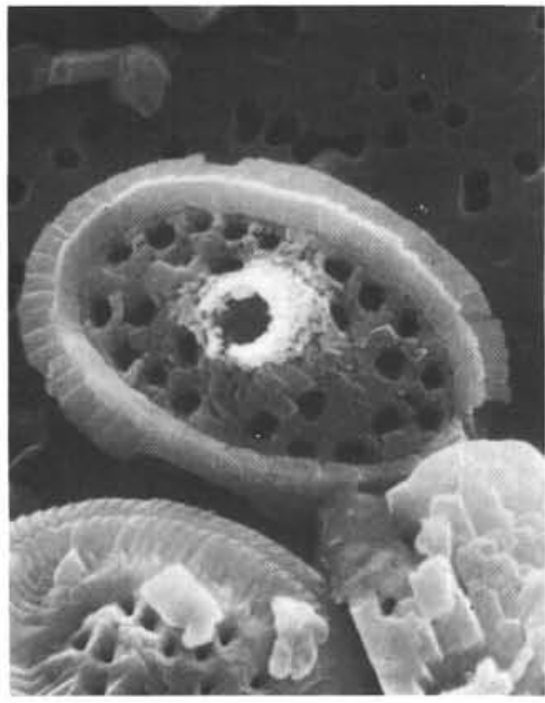

1

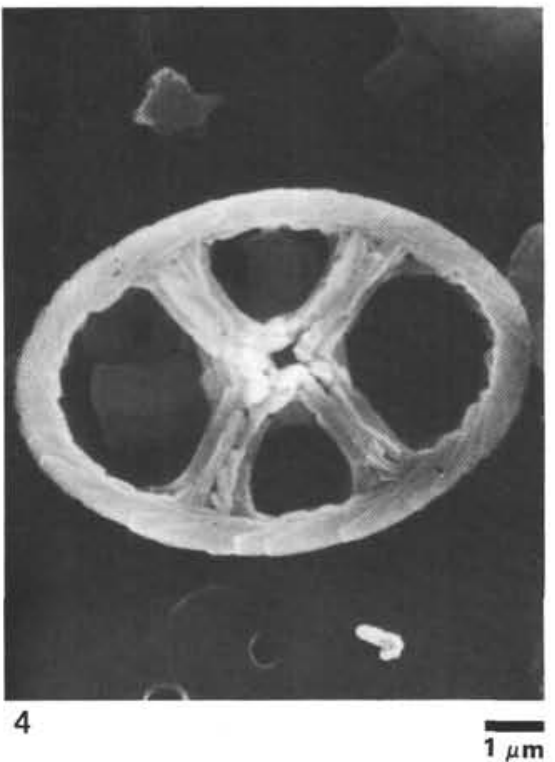

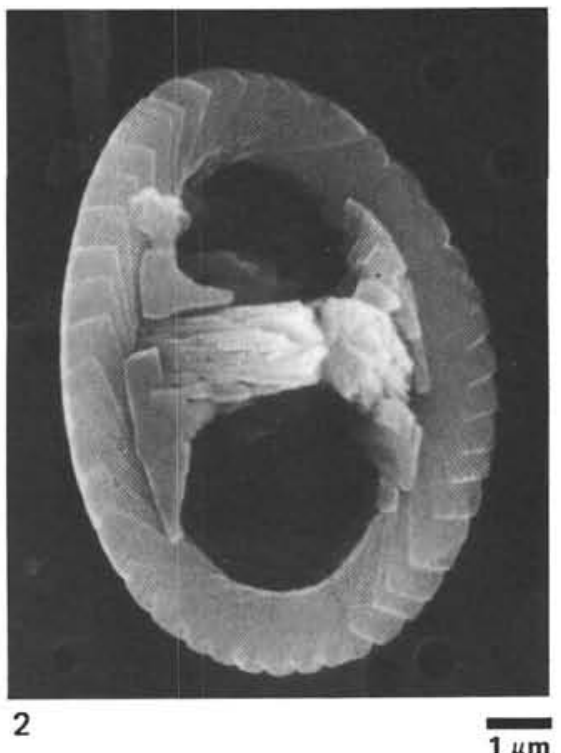
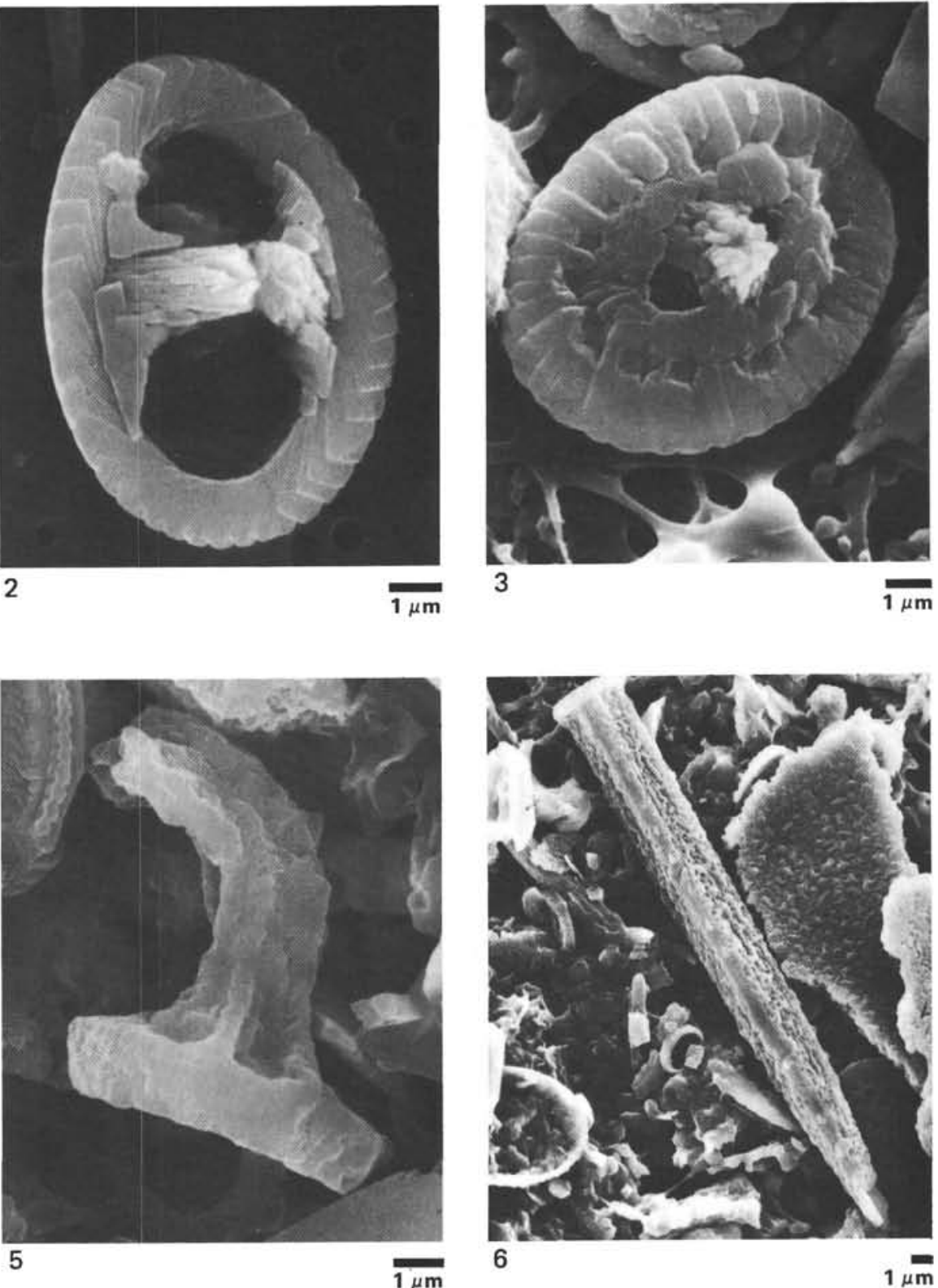

Plate 5. Calcareous nannoplankton from the Falkland Plateau. (All figures are scanning electron micrographs.) 1. Teichorhabdus ethmos Wind and Wise, distal view, $\times 4500$; Sample $511-24-7,13-15 \mathrm{~cm} . \quad 2$. Zygodiscus theta (Black) Bukry, distal view, $\times 6700$; Sample $511-24-6,26-28 \mathrm{~cm}$. 3. Reinhardtites sp. aff. $R$. anthophorus (Deflandre) Perch-Nielsen, $\times 6000$; Sample 511-24-3, 15-17 cm. 4. Chiastozygus garrisonii Bukry, distal view, $\times 6000$; Sample 511-24-1, 26-28 cm. 5. Lucianorhabdus sp. $\times 6000$; Sample $511-24-3,15-17 \mathrm{~cm}$. 6. Acuturris scotus (Risatti) Wind and Wise, $\times 2250$; specimen is $35 \mu \mathrm{m}$ long; Sample $511-24-3,15-17 \mathrm{~cm}$. 